\title{
Modulating the Gut Micro-Environment in the Treatment of Intestinal Parasites
}

\author{
Luis Vitetta ${ }^{1,2, *}$, Emma Tali Saltzman ${ }^{1,2}$, Tessa Nikov ${ }^{2}$, Isabelle Ibrahim ${ }^{2}$ and Sean Hall ${ }^{2}$ \\ 1 Sydney Medical School, The University of Sydney, Sydney 2006, NSW, Australia; \\ esal4025@uni.sydney.edu.au \\ 2 Medlab Clinical Ltd., Sydney 2015, NSW, Australia; tessa_nikov@medlab.co (T.N.); \\ isabelle_ibrahim@medlab.co (I.I.); sean_hall@medlab.co (S.H.) \\ * Correspondence: luis.vitetta@sydney.edu.au or luis_vitetta@medlab.co; Tel.: +61-2-809-419-39 \\ Academic Editor: Emmanuel Andrès \\ Received: 30 August 2016; Accepted: 10 November 2016; Published: 16 November 2016
}

\begin{abstract}
The interactions of micro-organisms cohabitating with Homo sapiens spans millennia, with microbial communities living in a symbiotic relationship with the host. Interacting to regulate and maintain physiological functions and immunological tolerance, the microbial community is able to exert an influence on host health. An example of micro-organisms contributing to an intestinal disease state is exhibited by a biodiverse range of protozoan and bacterial species that damage the intestinal epithelia and are therefore implicated in the symptoms of diarrhea. As a contentious exemplar, Blastocystis hominis is a ubiquitous enteric protist that can adversely affect the intestines. The symptoms experienced are a consequence of the responses of the innate immune system triggered by the disruption of the intestinal barrier. The infiltration of the intestinal epithelial barrier involves a host of immune receptors, including toll like receptors and $\operatorname{IgM} / \operatorname{IgG} / \operatorname{Ig} A$ antibodies as well as CD8+ T cells, macrophages, and neutrophils. Whilst the mechanisms of interactions between the intestinal microbiome and protozoan parasites remain incompletely understood, it is acknowledged that the intestinal microbiota is a key factor in the pathophysiology of parasitic infections. Modulating the intestinal environment through the administration of probiotics has been postulated as a possible therapeutic agent to control the proliferation of intestinal microbes through their capacity to induce competition for occupation of a common biotype. The ultimate goal of this mechanism is to prevent infections of the like of giardiasis and eliminate its symptoms. The differing types of probiotics (i.e., bacteria and yeast) modulate immunity by stimulating the host immune system. Early animal studies support the potential benefits of probiotic administration to prevent intestinal infections, with human clinical studies showing probiotics can reduce the number of parasites and the severity of symptoms. The early clinical indications endorse probiotics as adjuncts in the pharmaceutical treatment of protozoan infections. Currently, the bar is set low for the conduct of well-designed clinical studies that will translate the use of probiotics to ameliorate protozoan infections, therefore the requisite is for further clinical research.
\end{abstract}

Keywords: probiotics; protozoans; giardiasis; blastocystosis; intestinal dysbiosis

\section{Introduction}

Decades of research has revealed that the prevalence, persistence, and diversity of bacteria has been consistently undervalued [1] with life on this planet running concurrently with bacterial interactions at all levels of the living environment. Bacteria inhabit all manners of ecosystems including those found beneath the ice sheets in Antarctica [2] that contribute to sub-glacial aqueous environments, to those found in diverse geochemical environments of Yellowstone that host a variety of chemotrophic and phototrophic thermophilic communities [3]. It is therefore concluded that microbial communities 
form most of the world's biomass [4]. Reported estimates of bacterial mass suggest that there is approximately 40 million bacterial cells per gram of soil and one million bacterial cells per gram $(\mathrm{mL})$ of fresh water [4]. The human microbiome project reports that $90 \%$ of the cells in the human body belong to bacteria, fungal, or other non-human (e.g., parasites) elements [5] that can influence the host's health or disease state. Axenic experiments with rodents [6] have demonstrated that the microbiome community living on and within the mammalian host is able to shape its nutrient environment. A diverse and multifaceted environment emerges where, through the microbial interactions in the intestine, the gut microbiome is able to instruct the host in the complex language of molecular biology [7], allowing it to affect the pathogenesis of disease and infection.

There is a wide range of protozoans that are parasites of the human intestines. These protozoan species are not classified as a homogenous group. The physiology and biochemistry of human intestinal parasites are largely geared toward a parasitic habit [8]. The mechanisms of host penetration varies according to protozoan type, namely some species are intracellular parasites (e.g., Cryptosporidium spp.) and host specialized (e.g., Entamoeba histolytica), whereas others adapt to more than one host (e.g., Giardia intestinalis). Few species are reported to do any real damage to the host but some species can occasionally lead to common symptoms of diarrhea due to damage of the intestinal lining of the gut.

Studies report that protozoan pathogenesis largely results from parasitic biochemical products (e.g., proteinases) that can penetrate and damage the intestinal epithelial barrier, adversely affecting host inflammatory and immunological responses, as has been observed for Giardia [9] and Cryptosporidium [10]. The recognition of protozoans parasitizing mucosal surfaces in the intestines may involve the innate immune system/toll like receptors (TLRs) as shown through in vivo observations in individuals infected with Trichomonas vaginalis [11]. Furthermore, it has been reported that CD8+ T cells, macrophages, neutrophils, and IgM/IgG/IgA antibodies are major participants of the acquired immune response that is required for the resolution of giardiasis [8].

Although the pathogenicity of Blastocystis hominis is contentious, we propose that it forms part of the environment in the intestines of infected individuals. In fact, $B$. hominis is probably the most common protozoan detected in human faecal samples worldwide. Infection occurs in both immune-competent and immune-compromised individuals. Reported prevalence ranges from $2 \%-50 \%$ with the highest rates reported for developing countries with poor environmental hygiene. Infection appears to be more common in adults than in children [12,13].

The use of probiotics to modulate the gastrointestinal microbiome has been posited as a potential novel therapeutic agent [14]. It is hypothesized that probiotics have the capacity to control the proliferation of intestinal microbes by initiating competition for occupation of a common ecological niche. This mechanism aims to prevent protozoan infections of the like of Giardiasis and eliminate its symptoms. One of the many functions of the varying types of probiotics, including bacteria and yeasts, is to regulate immunity by stimulating the immune system within the host. Murine model studies (Table 1) support the use of probiotic administration as a therapeutic agent to prevent intestinal infections. Clinical studies (Table 2) have shown that probiotics can reduce the number of parasites and severity of associated symptoms. As such, early clinical indications support the use of probiotics as therapeutic adjuncts in the pharmaceutical treatment of protozoan infections. 
Table 1. Laboratory animal studies on the administration of probiotics to eradicate protist infections.

\begin{tabular}{|c|c|c|c|c|c|}
\hline Reference & Year & Study & Methods & Results & Conclusion \\
\hline [15] & 2008 & $\begin{array}{l}\text { Effect of Lactobacillus casei } \\
\text { as a probiotic on } \\
\text { modulation of giardiasis }\end{array}$ & $\begin{array}{l}\text { Group I = single dose of TYI-S-33 } \\
\text { Group II = Giardia-infected mice-single dose of Giardia trophozoites qid. } \\
\text { Group III = probiotic group } \\
\text { - IIIa: L. casei qid. for } 30 \text { days } \\
\text { - IIIb: isolated strain A (containing lactobacilli) qid. for } 30 \text { days } \\
\text { Group IV = Giardia-probiotic } \\
\text { - IV a: single dose of Giardia trophozoites \& L. casei for } 30 \text { days. } \\
\text { - } \quad \text { IV b: single dose of Giardia trophozoites and a single dose of isolated } \\
\text { strain A od. for } 30 \text { days } \\
\text { Group V = probiotic-Giardia-Probiotic treatment for } 30 \text { days after infective } \\
\text { dose of G. lamblia. } \\
\text { - Va: single dose of L. casei qid. for seven days then a single infective } \\
\text { dose of Giardia trophozoites. } \\
\text { Vb: single dose of isolated strain A qid. for seven days then a single } \\
\text { infective dose of Giardia trophozoites. }\end{array}$ & $\begin{array}{l}\text { - L. casei given seven days prior to } \\
\text { Giardia infection more effective and } \\
\text { efficient in eliminating infection } \\
\text { Probiotic-fed mice had less atrophied } \\
\text { villi and infiltrating cells in the } \\
\text { small intestine } \\
\text { - Ultrastructural studies with scanning } \\
\text { electron microscopy confirmed } \\
\text { protection of mice receiving L. casei } \\
\text { seven days prior to Giardia infection } \\
\text { and when simultaneously infected } \\
\text { with Giardia. }\end{array}$ & $\begin{array}{l}\text { Probiotics, particularly } \\
\text { L. casei, modulate } \\
\text { Giardia infection by } \\
\text { minimising or } \\
\text { preventing adherence of } \\
\text { Giardia trophozoites to } \\
\text { the mucosal surface, } \\
\text { suggesting probiotics } \\
\text { offer a safe and effective } \\
\text { mode to prevent and } \\
\text { treat Giardia infection. }\end{array}$ \\
\hline [16] & 1997 & $\begin{array}{l}\text { Effect of } L \text {. reuteri on } \\
\text { intestinal resistance to } \\
\text { C. parvum infection in } \\
\text { acquired immunodeficient } \\
\text { murine model }\end{array}$ & $\begin{array}{l}\text { - C57BL/ } 6 \text { immunosuppressed female mice with LP-BM5 } \\
\text { leukemia virus } \\
\text { - Four months after inoculation, mice developed susceptibility to } \\
\text { C. parvum infection. } \\
\text { - Daily prefeeding with L. reuteri }\left(10^{8} \text { cfu/day) for } 10 \text { days then }\right. \\
\text { challenged with } 6.5 \times 10^{6} \text { C. parvum oocysts } \\
\text { - Both groups fed L. reuteri for duration of study. }\end{array}$ & $\begin{array}{l}\text { - Supplemented mice cleared parasite } \\
\text { loads from the gut epithelium. } \\
\text { Control mice developed persistent } \\
\text { cryptosporidiosis,shed high levels of } \\
\text { oocysts in faeces and increased } \\
\text { colonization of the intestinal tract }\end{array}$ & $\begin{array}{l}\text { L. reuteri may help } \\
\text { prevent } C \text {. parvum } \\
\text { infection in } \\
\text { immune-deficient } \\
\text { subjects. }\end{array}$ \\
\hline [17] & 1999 & $\begin{array}{l}\text { Supplementation with } \\
\text { Lactobacillus reuteri or } \\
\text { L. acidophilus reduced } \\
\text { intestinal shedding of } \\
\text { cryptosporidium parvum } \\
\text { oocysts in } \\
\text { immunodeficient } \\
\text { C57BL/ } 6 \text { mice. }\end{array}$ & $\begin{array}{l}\text { C57BL/6 immunosuppressed female mice with LP-BM5 leukemia virus and } \\
\text { randomly assigned to one of five groups } \\
\text { - Group A: historical control } \\
\text { - Group B: LP-BM5 control } \\
\text { - Group C: C. parvum } \\
\text { - Group D: L. reuteri plus C. parvum } \\
\text { Mice pre-fed with L. reuteri or L. acidophilus for } 13 \text { days then challenged with } \\
\text { C. parvum oocysts and thereafter followed their allocated prescription. }\end{array}$ & $\begin{array}{l}\text { - Mice supplemented with } L \text {. reuteri } \\
\text { shed fewer }(p<0.05) \text { oocysts on } \\
\text { Day } 7 \text { post C. parvum challenge } \\
\text { Mice supplemented with } \\
\text { L. acidophilus shed fewer }(p<0.05) \\
\text { oocysts on days } 7 \text { and } \\
14 \text { post-challenge } \\
\text { Lactobacillus supplementation } \\
\text { reduced C. parvum shedding in the } \\
\text { feces but failed to suppress } \\
\text { production of IL-4 \& IL-8 \& restore } \\
\text { IL-2 \& IFN-gamma }\end{array}$ & $\begin{array}{l}\text { L. reuteri or L. acidophilus } \\
\text { can reduce C. parvum } \\
\text { parasite burdens in } \\
\text { epithelium during } \\
\text { cryptosporidiosis. } \\
\text { L. acidophilus was more } \\
\text { efficacious in reducing } \\
\text { fecal shedding than } \\
\text { L. reuteri }\end{array}$ \\
\hline
\end{tabular}


Table 2. Clinical studies on the administration of probiotics or pharmaceuticals to eradicate protist infections.

\begin{tabular}{|c|c|c|c|c|c|}
\hline Reference & Year & Study & Symptoms & Treatment & Results \\
\hline [18] & 2006 & $\begin{array}{l}\text { S. boulardii and infection due to } \\
\text { Giardia lamblia }\end{array}$ & $\begin{array}{l}\text { Enrolled participants showed } \\
\text { presence of G. lamblia } \\
\text { trophozoites or cysts in } \\
\text { stool specimens }\end{array}$ & $\begin{array}{l}\text { - } 10 \text { days } \\
\text { - } \quad \text { Sroup 1: Metroniardii bid. } 10 \text { days } \\
\text { - } \quad \text { Group 2: Metronidazole } 750 \mathrm{mg} \text { tid. } \\
\text { - } \quad \text { Placebo bid. }\end{array}$ & $\begin{array}{l}\text { - End of week 2, G. lamblia cysts detected in } \\
\text { - } 17.1 \% \text { of Group 2, but none in Group } 1 . \\
\text { microscopic findings } \\
\text { - } \quad 82.8 \% \text { of Group } 2 \text { had clearance of } \\
\text { microscopic findings }\end{array}$ \\
\hline [19] & 2011 & $\begin{array}{l}\text { Efficacy of S. boulardii or } \\
\text { metronidazole in symptomatic } \\
\text { children with Blastocystis hominis } \\
\text { infection }\end{array}$ & $\begin{array}{l}\text { - Gastrointestinal symptoms: } \\
\text { abdominal pain, diarrhea, } \\
\text { nausea-vomiting, flatulence } \\
\text { - } \quad \text { Positive stool examination for } \\
\text { Blastocystis hominis }\end{array}$ & $\begin{array}{l}\text { - Group A: Saccharomyces boulardii } 250 \mathrm{mg} \text { bid. } \\
\text { - } \quad \text { Group B: metronidazole } 30 \mathrm{mg} / \mathrm{kg} \text { bid. } \\
\quad \text { Group C: no treatment }\end{array}$ & $\begin{array}{l}\text { On day } 15 \text { clinical cure observed at: } \\
\text { - } \quad 77.7 \% \text { in Group A } \\
\text { - } \quad 66.66 \% \text { in Group B } \\
\text { On day } 15 \text { disappearance of cysts from stool was: } \\
\text { - } \quad 80 \% \text { in Group B } \\
\text { - } \quad 72.2 \% \text { in Group A } \\
\quad 26.6 \% \text { in Group C }\end{array}$ \\
\hline [20] & 2009 & $\begin{array}{l}\text { Efficacy of } S \text {. boulardii in children } \\
\text { with acute bloody diarrhea caused } \\
\text { by amebiasis }\end{array}$ & $\begin{array}{l}\text { - } \quad \text { Acute bloody diarrhea } \\
\text { - Presence of Entameba histolytica } \\
\text { cysts in stool }\end{array}$ & $\begin{array}{l}\text { - Metronidazole given to both groups } \\
\text { Intervention group: } 250 \mathrm{mg} \text { of } \\
\text { S. boulardii bid. }\end{array}$ & $\begin{array}{l}\text { Duration of bloody diarrhea was } \\
\text { significantly longer in control group } \\
\text { Day 5, all amebic cysts disappeared in children in } \\
\text { intervention group }\end{array}$ \\
\hline [21] & 2004 & $\begin{array}{l}\text { Resolution of cryptosporidiosis with } \\
\text { probiotic treatment-Case Study of } \\
12 \text { y.o. coeliac sufferer. }\end{array}$ & $\begin{array}{l}\text { - Four-month episode of } \\
\text { abdominal pain, flatulence, } \\
\text { nausea and lethargy. } \\
\text { - } \quad \text { Stool sample revealed } \\
\text { cryptosporidium oocysts } \\
\text { - Asymptomatic on a } \\
\text { gluten-free diet. }\end{array}$ & $\begin{array}{l}\text { - Patient received Lactobacillus GG } \\
10^{9} \text { units/day and Lactobacillus casei Shirota } \\
6.5 \times 10^{9} \text { units/day }\end{array}$ & $\begin{array}{l}\text { - Within } 10 \text { days, nausea and diarrhea } \\
\text { completely resolved and abdominal pain } \\
\text { was substantially reduced. } \\
\text { Repeat stool sample four weeks following } \\
\text { the start of probiotic treatment was clear of } \\
\text { cryptosporidium oocysts. }\end{array}$ \\
\hline [22] & 2003 & $\begin{array}{l}\text { Efficacy Saccharomyces boulardii } \\
\text { with antibiotics in acute amoebiasis }\end{array}$ & $\begin{array}{l}\text { Patients with acute intestinal } \\
\text { amoebiasis with clinical } \\
\text { manifestations of acute mucus } \\
\text { bloody diarrhea, and amebic } \\
\text { trophoxoites engulfing RBCs } \\
\text { found in stool specimens }\end{array}$ & 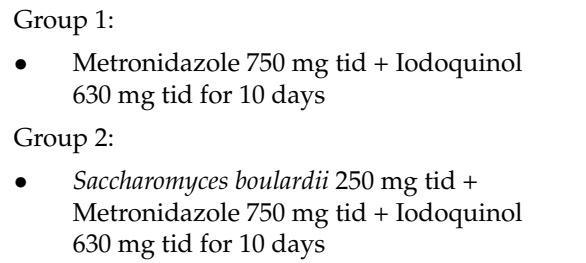 & $\begin{array}{l}\text { - At Week 4, amebic cysts were detected in five } \\
\text { cases of Group 1, but none in Group } 2 \text {. } \\
\text { Duration of symptoms was significantly less } \\
\text { in Group } 2 \text { compared to Group } 1 \text {. }\end{array}$ \\
\hline
\end{tabular}




\section{Methodology}

A systematic search of the literature was conducted using PubMed, the Cochrane Library, and CINAHL, as well as bibliographies of past research on the subject. Search terms were not limited by timeframe and therefore all searches were between July 2016 and the date of inception for each database. Articles were identified using the search terms ("Protist" OR "intestinal protozoan") AND ("dysbiosis") AND ("murine studies" or "human studies") AND ("probiotics" OR "pharmaceuticals") AND ("Lactobacilli" or "Bifidobacteria" or "Saccharomyces boulardii"). Inclusion criteria for this review were: (1) RCT and/or cross-over trials that used either placebo or current anti-infective medication or probiotics treatments; (2) Animal studies limited to probiotic or pharmaceutical treatments in laboratory mice or rats; and (3) articles published in English. Following the search, non-English papers were excluded from data extraction and analysis.

\section{Intestinal Environment Interactions between the Microbiota and Protozoans}

Although the interactions between the intestinal microbiome and protozoan parasites remain poorly understood [8], the intestinal microbiota represents an important actor in the pathophysiology of parasite infections.

Early murine studies have demonstrated that the intestinal microbiome could decrease susceptibility to Cryptosporidium parvum infections [23]. In contrast, other studies have shown that the intestinal microbiome was an essential factor for the expression of other pathogenic enteric parasites such as B. hominis [24] and E. histolytica [25]. Of significant interest has been a study on Giardia muris trophozoites with transmission electron microscopy [26] that showed bacterial endosymbionts within G. muris trophozoites have a role in both host protective and pathological mechanisms. It is speculated that this dual role is derived through altering the trophozoite antigencity. The protective role of bacterial endosymbionts within G. muris trophozoites was evident when trophozoites with endosymbionts were lysed when in close vicinity of the activated Paneth cells [26]. Such results support the hypothesis that the intestinal microbiota may directly and indirectly interfere with the pathogenesis of giardiasis.

In contrast, axenisation of the host at the intestinal level has been shown to promote the virulent expression of protozoan parasites. Studies with E. histolytica have demonstrated that interactions of amoebae of low pathogenicity with a variety of Gram-negative gut bacteria such as Escherichia coli strains could be responsible for the increased amoebic virulence [25]. Other studies have shown that the intestinal microbiota can stimulate the pathogenic expression but not the multiplication of parasites [27]. Torres and colleagues showed that the intestinal bacteria responsible for the stimulation of Giardia duodenalis pathogenicity dominate the duodenal microbiota [27]. Facultative and strictly anaerobic microbes from the duodenal microbiota were obtained from the biopsy of five children with symptomatic giardiasis. These microbes were then tested for their ability to stimulate G. duodenalis pathogenicity in gnotoxenic mice [27]. The germ-free animals did not develop intestinal pathological modifications during experimental Giardia infection, whilst further infected gnotoxenic mice showed intermediate pathological alterations between germ-free and infected conventional mice that were used as controls. No pathological changes were observed in non-infected gnotoxenic or conventional animals [27]. A hypothesis is suggested that bacterial components from the intestinal microbiota are required as stimulatory factors for intestinal pathogenic protozoans as well as for Giardia pathogenicity.

Modulation of the intestinal environment by probiotic bacteria can also serve as a trigger for controlling the proliferation of intestinal microbes and induces competition for the occupancy of a common biotope [28]. For example, Lactobacilli can limit nutrient availability. Such probiotic bacteria can render iron unavailable to pathogenic micro-organisms by either binding ferric hydroxide on its surface or by secreting siderophores (organic compounds produced by micro-organisms under conditions of low iron) that chelate and transport iron $[29,30]$.

Some probiotics are also able to influence the composition and equilibrium of the gut microbiota [31]. For example, probiotic therapy using a multi-species probiotic formulation increased the total number of intestinal bacteria and restored the microbiota's diversity in patients diagnosed with 
pouchitis [32]. Bifidobacteria shows efficacy in the allevation of gastrointestinal symptoms including constipation, abdominal discomfort, and flatulence through rebalancing of the gut microbiota [28]. Probiotic bacteria also exerts influence on the biotic environment by regulating the secretion of mucus and intestinal motility [28]. Probiotic bacteria can also secrete active molecules (i.e., bacteriocins, antibiotics, free fatty acids, and hydrogen peroxide [33]) that can control growth and/or survival of micro-organisms inhabiting the local intestinal areas [33]. Bacteriocins are secreted peptides or proteins that generally lyse closely related bacteria by permeabilizing bacterial membranes or by interfering with essential enzymes [31,33]. Lactobacilli probiotic strains produce various compounds-such as lactacin B, lactacin F, and nisin-that have bacteriocidal effects [34]. Lactobacillus reuteri produces reuterin (3-hydroxypropionaldehyde), a broad-spectrum antibiotic, that is active against bacteria, viruses, yeasts, fungi, and protozoa [34]. Lactic acid probiotic bacteria can also modify the growth of acid-sensitive organisms by lowering the local intestinal $\mathrm{pH}$ with the elaboration of lactic acid [29].

Probiotic bacteria can also modulate immunity by stimulating the host immune response to a variety of pathogens. In the intestine, probiotics interact with the epithelial cells, Peyer's patches, $M$ cells and immune cells [7]. These interactions result in an increase in the number of IgA producing cells accompanied by production of IgM and secretory IgA entities that are particularly important in mucosal immunity as they contribute to the barrier against pathogenic organisms [35]. In addition, probiotic bacteria can also affect dendritic cells, which are responsible for the collection of antigens from the intestine and their presentation to naive $\mathrm{T}$ cells which leads to their differentiation to T-helper (Th1, Th2) or T-regulatory lymphocytes. Probiotic molecules implicated in dendritic cell induction are poorly characterised with one exception being the S layer protein A of L. acidophilus NCFM that regulates maturation of dendritic cells and $\mathrm{T}$ cell functions [36].

Probiotics have also been shown to modulate cytokine release (TNF- $\alpha$ IFN- $\gamma$, IL-10, IL-12) [36]. Cytokine actions are important as they are central to maintaining intestinal homeostasis, the subtle balance that is required to maintain necessary and exhaustive defense mechanisms in the gut. Polysaccharide A, synthesized by the probiotic Bacillus fragilis, has been shown to protect against experimental colitis through a tolerable induction of IL-10 production [37].

\section{Probiotics for the Treatment of Protozoan Infections}

Intestinal protozoa can cause clinically significant infections in both the developed and developing words where the organisms are responsible for the occurrence of acute and chronic diarrhea [38]. The clinical impact of infection with intracellular intestinal protozoa (Cryptosporidium, Microsporidia, Cyclospora, Isospora) can be extremely damaging, especially in susceptible individuals who are immune incompetent. The administration of nitazoxanide (a substituted benzamide) and co-trimoxazole can effectively treat and clear Cryptosporidiosis and Cyclospora infections respectively [38]. However, the addition of these medications risks damaging the intestinal mucosa and micro-organism environment by disrupting the balance of the microbial composition [39].

Numerous laboratory animal studies (Table 1) have demonstrated that probiotic bacteria, such as the administration of Lactobacillus johnsonii [40] on G. lambia cysts in the feces of gerbils or the addition of Lactobacillus casei [15] as well as Enterococcus faecium (a species commonly found in the human gut microbiota) [41], have been able to effectively eliminate Giardia infections from mice. Mice that maintained an intact and competent immune system through probiotic treatment were refractory to C. parvum, with a compromised immune system altering cytokine production and leading to persistent cryptosporidiosis. Murine model studies have also demonstrated that $L$. reuteri supplementation can help prevent $C$. parvum $[16,17]$. These animal studies confirm that probiotics may confer benefits that strengthen host resistance to intestinal parasitic infections.

An early clinical study (Table 2) demonstrated that the beneficial effect of the administration of the probiotic yeast Saccharomyces boulardii is not directly related to its ability to prevent giardiasis but rather its capacity to assist with the recovery from post infection irritable bowel syndrome [42]. A later study from another group supported the earlier report by showing that $S$. boulardii reduced the number 
of parasite cysts in the feces from patients treated with the combination treatment of $S$. boulardii plus metronidazole versus patients treated by metronidazole only [18]. An additional clinical study that administered S. boulardii or metronidazole showed potential beneficial effects in B. hominis infection relative to a reduction of symptoms and presence of parasites [19].

\section{Discussion}

Intestinal microbial dysbiosis has been observed in extra-intestinal diseases and in particular those that may impact on the intestine-kidney axis or the intestine-liver axis to affect the adverse changes in end organ physiology [43]. Various factors influence the integrity of the intestinal barrier such as changes in intestinal permeability, mucin production and composition, and the homeostatic balance between the rate of apoptosis of damaged enterocytes to the rate of production of new enterocytes in the intestine [43].

It is reported that the mucosa of the small intestine is regenerated in its entirety every three to five days through the continuous cycle of proliferation, migration, and differentiation of the cells of the mucosa over the entire crypt-villus axis in the intestine [44]. This mucosal life cycle has led to the probing of probiotic bacteria and the yeast Saccharomyces boulardii as potential adjunct pharmaceutical treatments for intestinal protozoan infections that protect the intestinal epithelia from disruptive dysbiotic effects.

Protist infections with protozoans such as Blastocystis can alter human intestinal epithelial permeability by damaging the epithelia [45]. Animal and human studies that administered probiotic species to eradicate intestinal protozoans have demonstrated that probiotic bacteria and S. boulardii can modulate the intestinal environment by influencing local mucosal activity [46]. The effects of probiotic administration include a beneficial boost in $\mathrm{T}$ cells and the induction of immune-modulating proteins such as sIgA and a series of cytokines (Figure 1).

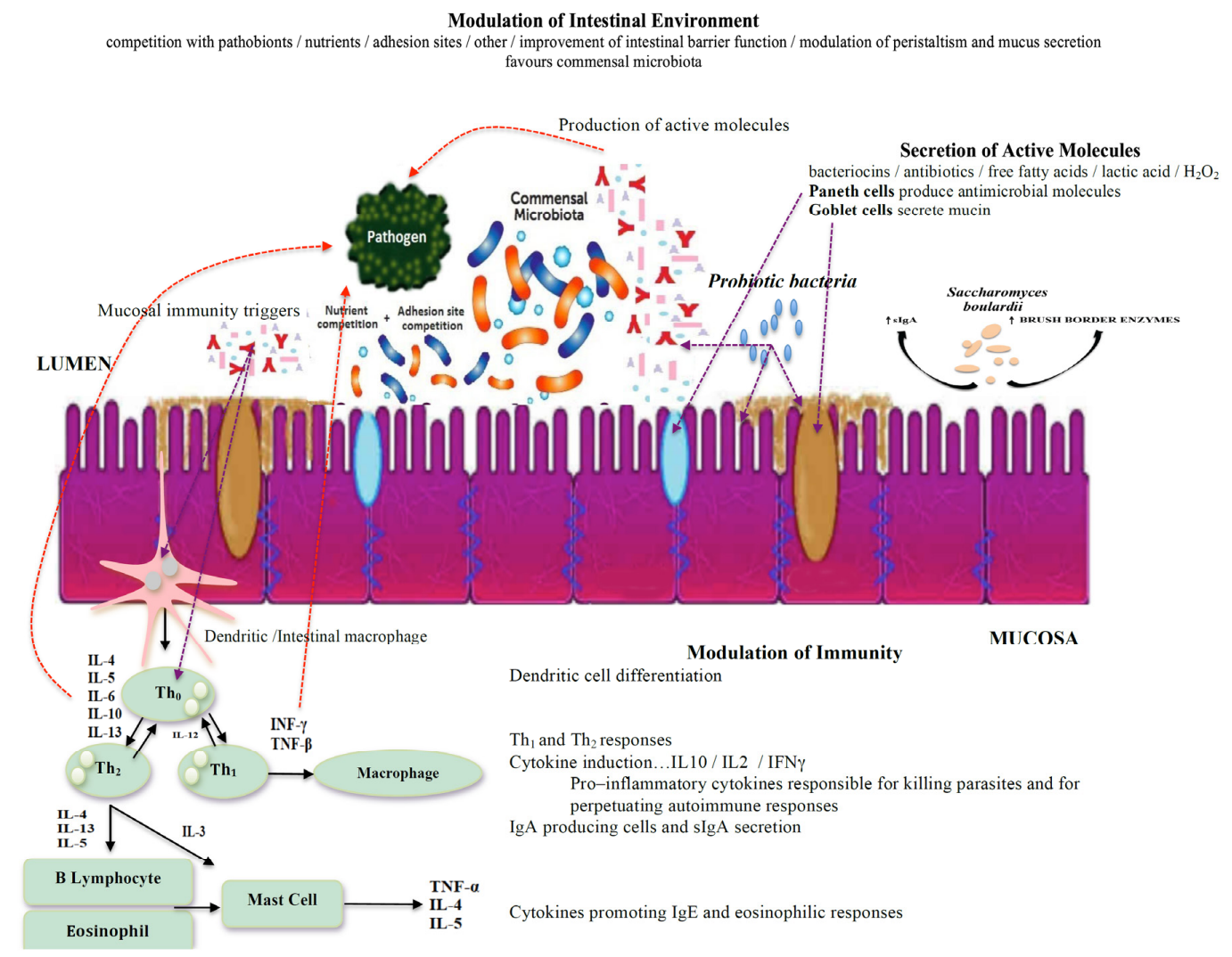

Figure 1. Schematic presentation of commensal, pathobiont, probiotic bacteria, and yeast interactions in the intestines with the production of antimicrobial compounds. Adapted from [47-49]. 
Furthermore, recent evidence suggests that the products of commensal intestinal microbes can help counter adverse inflammatory diseases in the host. Commensal bacteria in the colon are known to ferment dietary fibres to produce short-chain fatty acids. A mouse model from a colitis study demonstrated that these fatty acids downregulate innate and inflammatory responses through the stimulation of the chemo-attractant receptor GPR43 on neutrophils [50]. This activity strongly identifies interactions between short-chain fatty acids and GPR43 as a possible target for the manipulation of immune responses for therapeutic purposes. Moreover, the probiotic battery of multiple mechanisms for preventing infections, enhancing the immune system and providing immunomodulatory benefits includes an array of anti-microbial compounds that are capable of inhibiting the growth of pathogens, irrespective of the type of micro-organism that may overgrow or infect the intestines; namely bacteria, protozoans, and opportunistic pathogenic yeasts [51].

Probiotics are often classified as supplements of viable non-pathogenic micro-organisms (i.e., bacteria or yeast) that when orally administered can confer a health benefit to the host. Bacterial species of probiotics include Lactobacilli species, Bifidobacteria species, some Escherichia coli species, Streptococcus species, and the yeast Saccharomyces boulardii [52]. Herewith, we posit that probiotics are not supplements but rather medicines that confer positive health benefits through the modulation of the intestinal micro-environment [7]. Probiotic bacteria from the genus Lactobacilli and Bifidobacteria have been reported to contribute to a decrease in luminal $\mathrm{pH}$, stimulate epithelial cell growth and colonic blood flow, modify intestinal motility and absorb water and minerals, and increase the production of mucus [47].

\section{Conclusions}

It is evident that the microbial community of the human intestine is in a state of continuous flux, with the intestinal microbiome of a healthy adult composed of a stable balanced community of micro-organisms [53]. Comprising an ecosystem of living cells that interact with each other, an array of molecular compounds are produced which fine-tune the language of molecular biology in the intestine between micro-organisms and host cells that serve to maintain health or trigger disease. A symbiotic relationship therefore exists between the mammalian host and its intestinal microbiome. The disruption of this symbiotic relationship, termed dysbiosis, is the link used to implicate the intestinal microbiome in the pathogenesis of both disease and infection in the host. However, further research is warranted to clarify the mechanisms of action that lead the microbiome to initiate parasitic infections.

Modulating the intestinal microbial balance to restore balance is proposed as a possible therapeutic adjunct to attenuate or treat certain parasitic infections. One means of restoring homeostasis to the intestinal environment is the supplementation of probiotics. This review summarized animal studies and early clinical trials that administered probiotics and the yeast Saccharomyces boulardii to treat parasitic infections, with different probiotic strains, with S. boulardii having shown the capacity to reduce the symptoms of diarrheal infections and assist with recovery.

Conflicts of Interest: Luis Vitetta has received National Institute of Complementary Medicine and National Health and Medical Research Council of Australia competitive funding and Industry support for research into probiotics.

\section{References}

1. Bjorksten, B. The gut microbiota: A complex ecosystem. Clin. Exp. Allergy 2006, 36, 1215-1217. [CrossRef] [PubMed]

2. Christner, B.C.; Priscu, J.C.; Achberger, A.M.; Barbante, C.; Carter, S.P.; Christianson, K.; Michaud, A.B.; Mikucki, J.A.; Mitchell, A.C.; Skidmore, M.L.; et al. A microbial ecosystem beneath the West Antarctic ice sheet. Nature 2014, 512, 310-313. [CrossRef] [PubMed]

3. Wang, Y.; Boyd, E.; Crane, S.; Lu-Irving, P.; Krabbenhoft, D.; King, S.; Dighton, J.; Geesey, G.; Barkay, T. Environmental conditions constrain the distribution and diversity of archaeal merA in Yellowstone National Park, Wyoming, USA. Microb. Ecol. 2011, 62, 739-752. [CrossRef] [PubMed] 
4. Whitman, W.B.; Coleman, D.C.; Wiebe, W.J. Prokaryotes: The unseen majority. Proc. Natl. Acad. Sci. USA 1998, 95, 6578-6583. [CrossRef] [PubMed]

5. Turnbaugh, P.J.; Ley, R.E.; Hamady, M.; Fraser-Liggett, C.M.; Knight, R.; Gordon, J.I. The human microbiome project. Nature 2007, 449, 804-810. [CrossRef] [PubMed]

6. Hooper, L.V.; Midtvedt, T.; Gordon, J.I. How host-microbial interactions shape the nutrient environment of the mammalian intestine. Annu. Rev. Nutr. 2002, 22, 283-307. [CrossRef] [PubMed]

7. Vitetta, L.; Palacios, T.; Hall, S.; Coulson, S. Gastrointestinal Tract Commensal Bacteria and Probiotics: Influence on End-Organ Physiology. Prog. Drug Res. 2015, 70, 1-33. [PubMed]

8. Berrilli, F.; Di Cave, D.; Cavallero, S.; D'Amelio, S. Interactions between parasites and microbial communities in the human gut. Front. Cell. Infect. Microbiol. 2012, 2, 141. [CrossRef] [PubMed]

9. Scott, K.G.; Yu, L.C.; Buret, A.G. Role of CD8+ and CD4+ T lymphocytes in jejunal mucosal injury during murine giardiasis. Infect. Immun. 2004, 72, 3536-3542. [CrossRef] [PubMed]

10. Chai, J.Y.; Guk, S.M.; Han, H.K.; Yun, C.K. Role of intraepithelial lymphocytes in mucosal immune responses of mice experimentally infected with Cryptosporidium parvum. J. Parasitol. 1999, 85, 234-239. [CrossRef] [PubMed]

11. Zariffard, M.R.; Harwani, S.; Novak, R.M.; Graham, P.J.; Ji, X.; Spear, G.T. Trichomonas vaginalis infection activates cells through toll-like receptor 4. Clin. Immunol. 2004, 111, 103-107. [CrossRef] [PubMed]

12. Tan, K.S.; Singh, M.; Yap, E.H. Recent advances in Blastocystis hominis research: Hot spots in terra incognita. Int. J. Parasitol. 2002, 32, 789-804. [CrossRef]

13. Kaya, S.; Cetin, E.S.; Aridogan, B.C.; Arikan, S.; Demirci, M. Pathogenicity of Blastocystis hominis, a clinical reevaluation. Turkiye Parazitol. Derg. 2007, 31, 184-187. [PubMed]

14. Correia, M.I.T.D.; Liboredo, J.C.; Consoli, M.L.D. The roof of probiotics in gastrointestinal surgery. Nutrition 2012, 28, 230-234. [CrossRef] [PubMed]

15. Shukla, G.; Devi, P.; Sehgal, R. Effect of Lactobacillus casei as a probiotic on modulation of giardiasis. Dig. Dis. Sci. 2008, 53, 2671-2679. [CrossRef] [PubMed]

16. Alak, J.I.; Wolf, B.W.; Mdurvwa, E.G.; Pimentel-Smith, G.E.; Adeyemo, O. Effect of Lactobacillus reuteri on intestinal resistance to Cryptosporidium parvum infection in a murine model of acquired immunodeficiency syndrome. J. Infect. Dis. 1997, 175, 218-221. [CrossRef] [PubMed]

17. Alak, J.I.; Wolf, B.W.; Mdurvwa, E.G.; Pimentel-Smith, G.E.; Kolavala, S.; Abdelrahman, H.; Suppiramaniam, V. Supplementation with Lactobacillus reuteri or L. acidophilus reduced intestinal shedding of Cryptosporidium parvum oocysts in immunodeficient C57BL/6 mice. Cell. Mol. Biol. 1999, 45, 855-863. [PubMed]

18. Besirbellioglu, B.A.; Ulcay, A.; Can, M.; Erdem, H.; Tanyuksel, M.; Avci, I.Y.; Araz, E.; Pahsa, A. Saccharomyces boulardii and infection due to Giardia lamblia. Scand. J. Infect. Dis. 2006, 38, 479-481. [CrossRef] [PubMed]

19. Dinleyici, E.C.; Eren, M.; Dogan, N.; Reyhanioglu, S.; Yargic, Z.A.; Vandenplas, Y. Clinical efficacy of Saccharomyces boulardii or metronidazole in symptomatic children with Blastocystis hominis infection. Parasitol. Res. 2011, 108, 541-545. [CrossRef] [PubMed]

20. Dinleyici, E.C.; Eren, M.; Yargic, Z.A.; Dogan, N.; Vandenplas, Y. Clinical efficacy of Saccharomyces boulardii and metronidazole compared to metronidazole alone in children with acute bloody diarrhea caused by amebiasis: A prospective, randomized, open label study. Am. J. Trop. Med. Hyg. 2009, 80, 953-955. [PubMed]

21. Pickerd, N.; Tuthill, D. Resolution of cryptosporidiosis with probiotic treatment. Postgrad. Med. J. 2004, 80, 112-113. [CrossRef] [PubMed]

22. Mansour-Ghanaei, F.; Dehbashi, N.; Yazdanparast, K.; Shafaghi, A. Efficacy of Saccharomyces boulardii with antibiotics in acute amoebiasis. World J. Gastroenterol. 2003, 9, 1832-1833. [CrossRef] [PubMed]

23. Harp, J.A.; Chen, W.; Harmsen, A.G. Resistance of severe combined immunodeficient mice to infection with Cryptosporidium parvum: The importance of intestinal microflora. Infect. Immun. 1992, 60, 3509-3512. [PubMed]

24. Phillips, B.P.; Zierdt, C.H. Blastocystis hominis: Pathogenic potential in human patients and in gnotobiotes. Exp. Parasitol. 1976, 39, 358-364. [CrossRef]

25. Phillips, B.P.; Wolfe, P.A.; Rees, C.W.; Gordon, H.A.; Wright, W.H.; Reyniers, J.A. Studies on the ameba-bacteria relationship in amebiasis; comparative results of the intracecal inoculation of germfree, monocontaminated, and conventional guinea pigs with Entamoeba histolytica. Am. J. Trop. Med. Hyg. 1955, 4, 675-692. [PubMed] 
26. El-Shewy, K.A.; Eid, R.A. In vivo killing of Giardia trophozoites harbouring bacterial endosymbionts by intestinal Paneth cells: An ultrastructural study. Parasitology 2005, 130, 269-274. [CrossRef] [PubMed]

27. Torres, M.F.; Uetanabaro, A.P.; Costa, A.F.; Alves, C.A.; Farias, L.M.; Bambirra, E.A.; Penna, F.J.; Vieira, E.C.; Nicoli, J.R. Influence of bacteria from the duodenal microbiota of patients with symptomatic giardiasis on the pathogenicity of Giardia duodenalis in gnotoxenic mice. J. Med. Microbiol. 2000, 49, 209-215. [CrossRef] [PubMed]

28. Vitetta, L.; Hall, S.; Linnane, A.W. Live probiotic cultures and the gastrointestinal tract: Symbiotic preservation of tolerance whilst attenuating pathogenicity. Front. Cell. Infect. Microbiol. 2014, 4, 143. [CrossRef] [PubMed]

29. Oelschlaeger, T.A. Mechanisms of probiotic actions-A review. Int. J. Med. Microbiol. 2010, 300, 57-62. [CrossRef] [PubMed]

30. Elli M, Z.R.; Rytz, A.; Reniero, R.; Morelli, L. Iron requirement of Lactobacillus spp. in completely chemically defined growth media. J. Appl. Microbiol. 2000, 88, 695-703. [CrossRef] [PubMed]

31. Wohlgemuth, S.; Loh, G.; Blaut, M. Recent developments and perspectives in the investigation of probiotic effects. Int. J. Med. Microbiol. 2010, 300, 3-10. [CrossRef] [PubMed]

32. Kuhbacher, T.; Ott, S.J.; Helwig, U.; Mimura, T.; Rizzello, F.; Kleessen, B.; Gionchetti, P.; Blaut, M.; Campieri, M.; Fölsch, U.R.; et al. Bacterial and fungal microbiota in relation to probiotic therapy (VSL\#3) in pouchitis. Gut 2006, 55, 833-841. [PubMed]

33. Drider, D.; Bendali, F.; Naghmouchi, K.; Chikindas, M.L. Bacteriocins: Not Only Antibacterial Agents. Probiotics Antimicrob. Proteins 2016, 1-6. [CrossRef] [PubMed]

34. Cleusix, V.; Lacroix, C.; Vollenweider, S.; Le Blay, G. Glycerol induces reuterin production and decreases Escherichia coli population in an in vitro model of colonic fermentation with immobilized human feces. FEMS Microbiol. Ecol. 2008, 63, 56-64. [CrossRef] [PubMed]

35. Perdigon, G.; Alvarez, S.; Rachid, M.; Aguero, G.; Gobbato, N. Immune system stimulation by probiotics. J. Dairy Sci. 1995, 78, 1597-1606. [CrossRef]

36. Konstantinov, S.R.; Smidt, H.; de Vos, W.M.; Bruijns, S.C.; Singh, S.K.; Valence, F.; Molle, D.; Lortal, S.; Altermann, E.; Klaenhammer, T.R.; et al. S layer protein A of Lactobacillus acidophilus NCFM regulates immature dendritic cell and T cell functions. Proc. Natl. Acad. Sci. USA 2008, 105, 19474-19479. [CrossRef] [PubMed]

37. Arvola, T.; Laiho, K.; Torkkeli, S.; Mykkanen, H.; Salminen, S.; Maunula, L.; Isolauri, E. Prophylactic Lactobacillus GG reduces antibiotic-associated diarrhea in children with respiratory infections: A randomized study. Pediatrics 1999, 104, e64. [CrossRef] [PubMed]

38. Farthing, M.J. Treatment options for the eradication of intestinal protozoa. Nat. Clin. Pract. Gastroenterol. Hepatol. 2006, 3, 436-445. [CrossRef] [PubMed]

39. Carding, S.; Verbeke, K.; Vipond, D.T.; Corfe, B.M.; Owen, L.J. Dysbiosis of the gut microbiota in disease. Microb. Ecol. Health Dis. 2015, 26, 26191. [CrossRef] [PubMed]

40. Humen, M.A.; de Antoni, G.L.; Benyacoub, J.; Costas, M.E.; Cardozo, M.I.; Kozubsky, L.; Saudan, K.Y.; Boenzli-Bruand, A.; Blum, S.; Schiffrin, E.J.; et al. Lactobacillus johnsonii La1 antagonizes Giardia intestinalis in vivo. Infect. Immun. 2005, 73, 1265-1269. [CrossRef] [PubMed]

41. Benyacoub, J.; Perez, P.F.; Rochat, F.; Saudan, K.Y.; Reuteler, G.; Antille, N.; Humen, M.; De Antoni, G.L.; Cavadini, C.; Blum, S.; et al. Enterococcus faecium SF68 enhances the immune response to Giardia intestinalis in mice. J. Nutr. 2005, 135, 1171-1176. [PubMed]

42. Castaneda, C.; Guillot, E.G.B.; Santa Cruz, M.; Dominguez, M.F.; Garcia, E.; Gutierrez, P.M. Effects of Saccharomyces boulardii in children with chronic diarrhea, especially cases due to giardiasis. Revista Mexicana de Puericultura y Pediatria 1995, 2, 1-11.

43. Vitetta, L.; Manuel, R.; Zhou, J.Y.; Linnane, A.W.; Hall, S.; Coulson, S. The overarching influence of the gut microbiome on end-organ function: The role of live probiotic cultures. Pharmaceuticals (Basel) 2014, 7, 954-989. [CrossRef] [PubMed]

44. Bellafante, E.; Morgano, A.; Salvatore, L.; Murzilli, S.; Di Tullio, G.; D’Orazio, A.; Latorre, D.; Villani, G.; Moschetta, A. PGC-1 $\beta$ promotes enterocyte lifespan and tumorigenesis in the intestine. Proc. Natl. Acad. Sci. USA 2014, 111, E4523-E4531. [CrossRef] [PubMed] 
45. Boorom, K.F.; Smith, H.; Nimri, L.; Viscogliosi, E.; Spanakos, G.; Parkar, U.; Li, L.H.; Zhou, X.N.; Ok, U.Z.; Leelayoova, S.; et al. Oh my aching gut: Irritable bowel syndrome, Blastocystis, and asymptomatic infection. Parasit. Vectors 2008, 1, 40. [CrossRef] [PubMed]

46. O'Flaherty, S.; Saulnier, D.M.; Pot, B.; Versalovic, J. How can probiotics and prebiotics impact mucosal immunity? Gut Microbes 2010, 1, 293-300. [CrossRef] [PubMed]

47. Ohashi, Y.; Ushida, K. Health-beneficial effects of probiotics: Its mode of action. Anim. Sci. J. 2009, 80, 361-371. [CrossRef] [PubMed]

48. Travers, M.A.; Florent, I.; Kohl, L.; Grellier, P. Probiotics for the control of parasites: An overview. J. Parasitol. Res. 2011, 2011, 610769. [CrossRef] [PubMed]

49. McFarland, L.V. Systematic review and meta-analysis of Saccharomyces boulardii in adult patients. World J. Gastroenterol. 2010, 16, 2202-2222. [CrossRef] [PubMed]

50. Maslowski, K.M.; Vieira, A.T.; Ng, A.; Kranich, J.; Sierro, F.; Yu, D.; Schilter, H.C.; Rolph, M.S.; Mackay, F.; Artis, D.; et al. Regulation of inflammatory responses by gut microbiota and chemoattractant receptor GPR43. Nature 2009, 461, 1282-1286. [CrossRef] [PubMed]

51. Galdeano, C.M.; de Moreno de LeBlanc, A.; Vinderola, G.; Bonet, M.E.; Perdigon, G. Proposed model: Mechanisms of immunomodulation induced by probiotic bacteria. Clin. Vaccine Immunol. 2007, 14, 485-492. [CrossRef] [PubMed]

52. Antoine, J.M. Probiotics: Beneficial factors of the defence system. Proc. Nutr. Soc. 2010, 69, 429-433. [CrossRef] [PubMed]

53. Martin, R.; Miquel, S.; Ulmer, J.; Langella, P.; Bermudez-Humaran, L.G. Gut ecosystem: How microbes help us. Benef. Microbes 2014, 5, 219-233. [CrossRef] [PubMed]

(C) 2016 by the authors; licensee MDPI, Basel, Switzerland. This article is an open access article distributed under the terms and conditions of the Creative Commons Attribution (CC-BY) license (http:/ / creativecommons.org/licenses/by/4.0/). 